Borys V. Horlynskyi ${ }^{1}$, Head of Office of Department ORCID ID 0000-0002-9993-2427 e-mail:vjzgoxnf@gmail.com

Sergei V. Zaitsev ${ }^{2}$, Professor of the Department ORCID ID 0000-0001-6643-917X e-mail: serza1979@gmail.com

Svitlana P. Kaznadiy ${ }^{2}$, Senior Lecturer

ORCID ID 0000-0001-8516-0801 e-mail: kaznadeysp@gmail.com

Lilia I. Zaitseva ${ }^{3}$, Technician

ORCID ID 0000-0002-0668-711X e-mail: serza1979@gmail.com

${ }^{1}$ Administration of State Service of Special Communication and Information Protection of Ukraine, Kyiv, Ukraine

${ }^{2}$ Chernihiv National University of Technology, Chernihiv, Ukraine

${ }^{3}$ State Service of Special Communication and Information Protection, Chernihiv, Ukraine

\title{
FORMALIZATION OF THE MATHEMATICAL MODELING PROCESS OF ADAPTIVE CHANGE OF CODE STRUCTURE IN WIRELESS DATA TRANSMISSION
}

Abstract. The formalization of the process of structural adaptation of turbo codes under the conditions of noise interference, which lead to uncertainty in the process of decoding of correction codes, is proposed. The essence of formalization lies in the adaptive choice of the structure of the correction code using the a priori and a posteriori information of the decoder at the expense of minimizing the average risk. The proposed results can be used to ensure the reliability of information transfer systems that operate in the face of powerful interference.

Keywords: correction codes; turbo codes; adaptation; decoding algorithms; interference 


\title{
Б.В. Горлинський ${ }^{1}$, С.В. Зайцев ${ }^{2}$, С.П. Казнадій ${ }^{2}$, Л.І. Зайцева ${ }^{3}$
}

${ }^{1}$ Адміністрація Державної служби спеціального зв'язку та захисту інформації України, м. Київ, Україна

${ }^{2}$ Чернігівський національний технологічний університет, м. Чернігів, Україна

${ }^{3}$ Державна служба спеціального зв'язку та захисту інформації України, м. Чернігів, Україна

\section{ФОРМАЛІЗАЦІЯ ПРОЦЕСУ МАТЕМАТИЧНОГО МОДЕЛЮВАННЯ АДАПТИВНОЇ ЗМІНИ СТРУКТУРИ КОДІВ В БЕЗПРОВОДОВИХ ЗАСОБАХ ПЕРЕДАЧІ ДАНИХ}

\begin{abstract}
Анотація. Запропонована формалізація процесу структурної адаптації турбо кодів за умов впливу завад, які призводять до виникнення невизначеності в прочесі декодування корегувальних кодів. Сутність формалізаиії полягає у адаптивному виборі структури корегувального коду з використанням апріорної та апостеріорної інформачії декодера за рахунок мінімізаиії середнього ризику. Запропоновані результати можна використати для забезпечення достовірності систем передачі інформації, які функиіонують в умовах впливу потужних завад.
\end{abstract}

Ключові слова: коригувальні коди; турбо коди; адаптачія; алгоритми декодування; завади

\section{Постановка проблеми}

Основними видами завад $є$ : шумова загороджувальна завада, шумова завада в частині смуги і завада у відповідь, моделі яких представляють обмежений по смузі частот адитивний білий гаусівський шум (АБГШ) [1]. В якості методів захисту від навмисних завад застосовують метод псевдовипадкової перебудови робочої частоти та корегувальні коди, такі як циклічні коди, коди БЧХ, Ріда-Соломона та інші.

Найбільш ефективними серед всього класу корегувальних кодів є турбо коди (ТК). За енергетичною ефективністю ТК поступаються теоретичному граничному значенню для швидкості кодування $\mathrm{R}=1 / 3$ лише 0,5 дБ [2]. Турбо коди застосовуються в системах мобільного зв'язку третього покоління $3 \mathrm{G}$ (cdma2000, cdma2000 1xEV-DO, cdma2000 1xEV-DV, UMTS), четвертого покоління 4G (LTE), в системах зв'язку з далеким космосом CCSDS для передачі телеметричної інформації 3 космічних апаратів, в системах супутникового цифрового телебачення DVB-RCS [3-8].

Вимагає розгляду питання застосування адаптивних турбо кодів в умовах впливу завад, які б змінювали свої параметри в залежності від стану каналу для забезпечення заданих характеристик достовірності передачі інформації.

\section{Аналіз досліджень і публікацій}

В роботах [9-10] досліджуються схеми адаптації сигнально-кодових конструкцій (зміна позиційності сигналу та швидкості кодування завадостійкого коду) систем WiMax та LTE за первинними параметрами в залежності від відношення сигнал-шум в каналі передачі. При цьому розглядаються канали 3 адитивним білим гаусівським шумом, Релеївськими завмираннями, 
Райсовськими завмираннями та завмираннями Накагамі. В роботах інших авторів [11-14] адаптація відбувається теж за рахунок зміни позиційності сигналу та швидкості кодування, але вже за вторинними параметрами в залежності від значень відношення сигнал-шум розраховуються значення ймовірності помилки для різних схем модуляцій сигналу та здійснюється порівняння цього значення із заданими, i в залежності від результатів порівняння здійснюється вибір необхідної сигнально-кодової конструкції.

\section{Виділення не вирішених раніше частин загальної проблеми}

Недоліком зазначених схем адаптації $€$ те, що первинним параметром при адаптації є відношення сигнал-шум, а також те, що вони не враховують при адаптації результати декодування, що може призвести до неточності прийняття рішень, особливо за умов потужних завад.

\section{Мета статті}

Метою статті $\epsilon$ розробка процесу формалізації структурної адаптації корегувальних кодів за умов впливу завад за рахунок мінімізації середнього ризику з використанням апріорної та апостеріорної інформації декодера турбо коду.

\section{Виклад основного матеріалу}

При знаходженні оптимальних (раціональних) динамічних систем, функціонуючих в умовах впливу випадкових завад, застосовують статистичні критерії якості, за допомогою яких оцінюють середні значення вихідних характеристик для великого числа реалізацій процесів на входах системи. Як приклади таких статистичних критеріїв якості можна навести наступні: відношення потужності сигналу до потужності шуму або енергії сигналу до спектральної щільності шуму на виході приймача; величина середнього квадрата помилки оцінки деякої фізичної величини; ймовірність помилок при перевірці всіляких гіпотез; середній час до ухвалення рішення із заданою ймовірністю помилок при нефіксованому часі спостереження випадкових вхідних величин.

Синтез оптимальних (раціональних) систем при випадкових вхідних діях зводиться до вибору параметрів або виду систем, що мінімізують або максимізували відповідні статистичні критерії якості [15].

Розглядаються схеми каскадного кодування кодів Ріда-Соломона, БЧХ-кодів в поєднанні з турбокодами.

Нехай послідовність на виході кодера ТК має вигляд: $\bar{X}=\left(\bar{X}^{\mathrm{c}}, \bar{X}^{\Pi}\right)$, де $\bar{X}^{\mathrm{c}}=\bar{U}$ - систематичний вихід кодера, а $\bar{X}^{\Pi}=\left(\bar{X}^{\Pi 1}, \bar{X}^{\Pi 2}\right)-$ перевірочні виходи кодера ТК розмірності $v$, де $v$ - загальна кількість перевірочних символів кожного рекурсивного систематичного згорточного коду. Передбачається, що канал зв'язку дискретно-неперервний і має ідеальну імпульсну характеристику $h_{c}(t)=1$, внаслідок чого сигнал спотворюється тільки присутністю білого гаусівського шуму. 3 виходу каналу послідовність символів подається на 
декодер ТК кожної ітерації декодування: $\bar{Y}^{1}=\left(L_{c} \bar{Y}^{\mathrm{c} 1}, L_{c} \bar{Y}^{\Pi 1}\right)-$ для декодера 1 , де $\bar{Y}^{\Pi 1}=\left(\bar{Y}^{\Pi 11}, \ldots, \bar{Y}^{\Pi 1 v}\right)$, а $\bar{Y}^{2}=\left(L_{c} \bar{Y}^{\mathrm{C2}}, L_{c} \bar{Y}^{\Pi 2}\right)$ - для декодера 2 , де $\bar{Y}^{\Pi 2}=\left(\bar{Y}^{\Pi 21}, \ldots, \bar{Y}^{\Pi 2 v}\right)$. У цьому випадку $\bar{Y}^{\mathrm{c} 1}=\bar{Y}^{\mathrm{c}}, \bar{Y}^{\mathrm{c} 2}-$ послідовності систематичних символів з урахуванням відповідної операції перемеження, а $L_{c}$ - параметр «канальної надійності», що характеризує «зашумленість» каналу передачі інформації [16]. У наведеній схемі можуть бути використані перемежувачі різних видів, наприклад псевдовипадковий перемежувач/деперемежувач, $S$-випадковий, діагональний і т.д.

Розглянемо більш докладно роботу декодерів 1, 2 на $j$-й ітерації декодування по декодуванню $t$-го біта, $j \in \overline{1, I}, t \in \overline{1, N}$, де $I$ - загальна кількість ітерацій декодування, $N$ - загальна кількість бітів у переданому блоці даних. Структурна схема декодера турбо коду з модулями розрахунку критеріїв ризику $R^{d, j}, R_{\Sigma}$, $R\left(\Phi_{N 0}\right)$ і модулем управління (структурою коригувальних кодів), який формує множину рішень вибору параметрів $U=\left(u_{1}, u_{2}, u_{3}, \ldots, u_{N}\right)$, що передаються до кодера й декодера ТК, а також до інших кодів, показана на рис. 1.

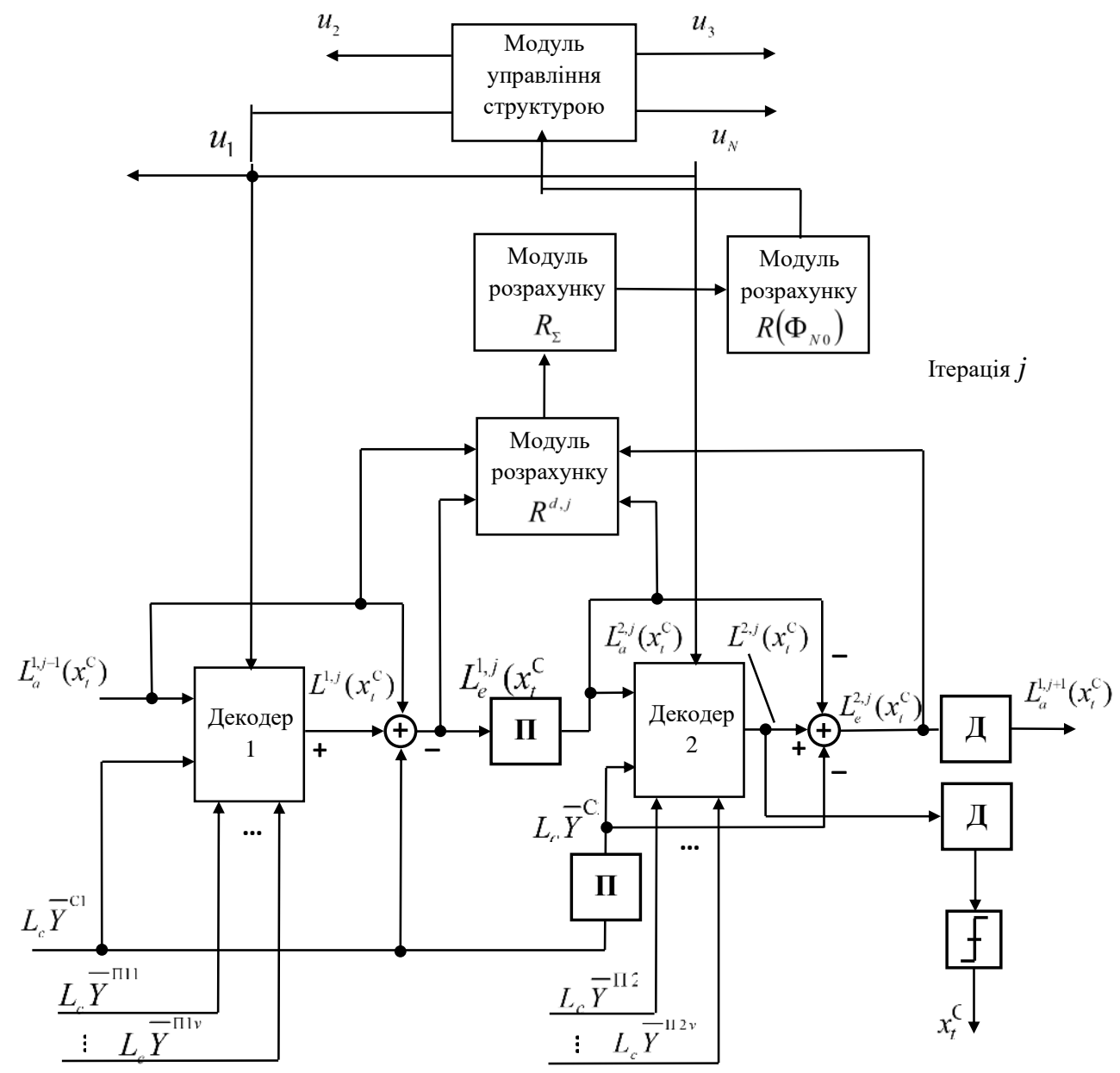

Рис. 1 - Структурна схема адаптивного декодера турбо коду 
Як параметри ТК, які адаптуються до середовища передачі, розглядаються поліноми рекурсивних систематичних згорточних кодів $\left(1, g_{1} / g_{0}\right)$, алгоритми перемеження (регулярні або псевдовипадкові), кількість бітів у блоці $N$, швидкість кодування турбо коду $R$, алгоритми декодування (Map, Max Log Map, Log Map), кількість ітерацій декодування $I$.

Нехай $x_{t}$ - це переданий $t$-й біт, а $y_{t}-$ прийнятий $t$-й біт, який спотворений впливом білого гаусівського шуму. Оскільки у каналах з підвищеним рівнем шуму на прийомній стороні приймаються рішення в умовах невизначеності, то «м'яке» рішення або логарифмічне відношення функцій правдоподібності (ЛВФП), що розраховується декодером 1 на $j$-й ітерації, визначається наступним виразом [16]:

$$
L^{1, j}\left(x_{t} \mid y_{t}\right)=\ln \frac{P\left(y_{t} \mid x_{t}=+1\right)}{P\left(y_{t} \mid x_{t}=-1\right)}+\ln \frac{P\left(x_{t}=+1\right)}{P\left(x_{t}=-1\right)}=L_{a}^{1, j}\left(x_{t}\right)+L^{1, j}\left(y_{t} \mid x_{t}\right),
$$

де $L^{1, j}\left(y_{t} \mid x_{t}\right)$ - ЛВФП, що виходить шляхом виміру $y_{t}$ на виході каналу при чергуванні умов, що може бути переданий $x_{t}=+1$ або $x_{t}=-1$, а $L_{a}^{1, j}\left(x_{t}\right)-$ апріорне ЛВФП біта даних $x_{t}$. Для спрощення рівняння (1) може бути переписане таким чином:

$$
L^{1, j}\left(x_{t}\right)=L_{c}^{1, j}\left(y_{t}\right)+L_{a}^{1, j}\left(x_{t}\right)+L_{e}^{1, j}\left(x_{t}\right),
$$

де $L_{c}^{1, j}\left(y_{t}\right)$ - параметр «канальної надійності», $L_{e}^{1, i}\left(x_{t}\right)$ - апостеріорне ЛВФП біта даних $x_{t}$.

Далі розраховується апостеріорне ЛВФП біта даних $x_{t}-L_{e}^{1, j}\left(x_{t}\right)$ :

$$
L_{e}^{1, j}\left(x_{t}\right)=L^{1, j}\left(x_{t}\right)-L_{c}^{1, j}\left(y_{t}\right)-L_{a}^{1, j}\left(x_{t}\right) .
$$

Перемежувач перетворить апостеріорне ЛВФП $L_{e}^{1, j}\left(x_{t}\right)$ в апріорне ЛВФП $L_{a}^{2, j}\left(x_{t}\right): L_{a}^{2, j}\left(x_{t}\right)=f_{1}\left(L_{e}^{1, j}\left(x_{t}\right)\right)$, що подається на декодер 2. Декодер 2 виконує наступні обчислення для одержання апостеріорного ЛВФП біта даних $x_{t}-$ $L_{e}^{2, j}\left(x_{t}\right)$ :

$$
L_{e}^{2, j}\left(x_{t}\right)=L^{2, j}\left(x_{t}\right)-L_{c}^{2, j}\left(y_{t}\right)-L_{a}^{2, j}\left(x_{t}\right) .
$$

Після операції деперемеження $L_{a}^{1, j+1}\left(x_{t}\right)=f_{2}\left(L_{e}^{2, j}\left(x_{t}\right)\right)$ величина $L_{a}^{1, j+1}\left(x_{t}\right)$ використовується в якості апріорної для декодера 1 ітерації $j+1$. Далі здійснюються обчислення аналогічні (3) і (4).

Після виконання необхідної кількості ітерацій, або у випадку примусової зупинки ітеративної процедури декодування, виносяться «тверді» рішення про декодовані символи:

$$
x_{t}^{\mathrm{c}}=\left\{\begin{array}{l}
1, \text { если } L\left(x_{t}^{\mathrm{c}}\right) \geq 0 \\
0, \text { если } L\left(x_{t}^{\mathrm{c}}\right)<0
\end{array}\right. \text {. }
$$


Результати імітаційного моделювання показали, що якщо в процесі декодування змін знака в значеннях $L_{a}^{d, j}\left(x_{t}^{\mathrm{c}}\right)$ й $L_{e}^{d, j}\left(x_{t}^{\mathrm{c}}\right)$, де $d$-поточний декодер ТК, $d \in \overline{1,2}$, ітерації $j$, не відбувається, то після кожного наступного декодера значення ЛВФП про переданий біт будуть або зменшуватися (якщо був переданий біт «0»), або збільшуватися (якщо був переданий біт «1»). Після виконання заданої кількості ітерацій декодування виноситься «тверде» рішення про декодований біт. Може виникнути ситуація (внаслідок великого значення дисперсії шуму в каналі), що після виконання процедур ітеративного декодування всіма декодерами кількість змін знака значень апріорної $L_{a}^{d, j}\left(x_{t}^{\mathrm{c}}\right)$ й апостеріорної інформацій $L_{e}^{d, j}\left(x_{t}^{\mathrm{c}}\right)$ на останньому декодері останньої ітерації не дорівнює нулю. Подібні ситуації призводять до виникнення помилок декодування.

Розглянутий вище показник ризику (невизначеності) $R$ будемо використовувати для оцінки якості процесу декодування в умовах впливу навмисних завад. При обчисленні значення показника ризику будемо враховувати зміни знака значень апріорної $L_{a}^{2, j}\left(x_{t}^{\mathrm{c}}\right)$ й апостеріорної інформацій $L_{e}^{2, j}\left(x_{t}^{\mathrm{c}}\right)$ декодера 2 ітерації $j, j \in \overline{1, I}$, у процесі декодування всього блоку даних розміром $N$.

Насправді існують три події про прийняття рішень при декодуванні декодером $d, d \in \overline{1,2}$, ітерації декодування $j, j \in \overline{1, I}$ біта інформації:

1) подія $A_{1}$. Змін знака в значеннях $L_{a}^{d, j}\left(x_{t}^{\mathrm{c}}\right)$ й $L_{e}^{d, j}\left(x_{t}^{\mathrm{C}}\right)$ ітерації $j$ не відбувається $\left(\operatorname{sign}\left(L_{a}^{d, j}\left(x_{t}^{\mathrm{c}}\right)\right)=\operatorname{sign}\left(L_{e}^{d, j}\left(x_{t}^{\mathrm{c}}\right)\right) \quad\right), \quad L\left(x_{t}^{\mathrm{c}}\right) \geq 0$. Прийняте «тверде» рішення, що був переданий біт $x_{t}^{\mathrm{c}}=1$.

2) подія $A_{2}$. Змін знака в значеннях $L_{a}^{d, j}\left(x_{t}^{\mathrm{c}}\right)$ й $L_{e}^{d, j}\left(x_{t}^{\mathrm{c}}\right)$ ітерації $j$ не відбувається $\left(\operatorname{sign}\left(L_{a}^{d, j}\left(x_{t}^{\mathrm{c}}\right)\right)=\operatorname{sign}\left(L_{e}^{d, j}\left(x_{t}^{\mathrm{c}}\right)\right) \quad\right), \quad L\left(x_{t}^{\mathrm{c}}\right)<0$. Прийняте «тверде» рішення, що був переданий біт $x_{t}^{\mathrm{c}}=0$.

3 ) подія $A_{3}$. Знак значення апріорної $L_{a}^{d, j}\left(x_{t}^{\mathrm{c}}\right)$ й знак значення апостеріорної інформацій $L_{e}^{d, j}\left(x_{t}^{\mathrm{c}}\right)$ ітерації $j$ не дорівнює нулю $\left(\operatorname{sign}\left(L_{a}^{d, j}\left(x_{t}^{\mathrm{c}}\right)\right) \neq \operatorname{sign}\left(L_{e}^{d, j}\left(x_{t}^{\mathrm{c}}\right)\right)\right)$. Можуть виникнути помилки декодування.

Показник ризику для декодера $d, d \in \overline{1,2}$, ітерації декодування $j, j \in \overline{1, I}$, обчислюється за допомогою наступної процедури:

$$
\begin{gathered}
\sum_{d=1}^{2} R^{d, j}(t+1)=R^{d, j}(t)+1, \\
\text { якщо } \operatorname{sign}\left(L_{a}^{d, j}\left(x_{t}^{\mathrm{C}}\right)\right) \neq \operatorname{sign}\left(L_{e}^{d, j}\left(x_{t}^{\mathrm{C}}\right)\right), t \in \overline{1, N} .
\end{gathered}
$$

Чим частіше збільшуються значення показника ризику $R$, тим частіше з'являються невірно декодовані біти, що призводить до погіршення достовірності прийому інформації.

Сумарний показник ризику $R_{\Sigma}$ визначається сумою показників ризику для всіх ітерацій декодування:

$$
R_{\Sigma}=\sum_{j=1}^{I} R^{d, j} .
$$


В основі формалізації та побудови математичної моделі лежить неформальний опис безпроводових засобів передачі даних (БЗПД).

Неформальним описом БЗПД називається вся наявна про них сукупність відомостей, достатня для встановлення передбачуваного або фактичного алгоритму їх роботи. Неформальний опис БЗПД повинен містити інформацію, достатню для побудови їх функціональних схем. Останні $є$ основою для розробки формального опису, 3 якого далі можна одержати бажану математичну модель.

Опис БЗПД, складений по узагальненій функціональній схемі 3 використанням певного базису операторів, що дозволяють по вхідних впливах знайти реакцію БЗПД в загальному виді, назвемо узагальненою математичною моделлю або формальним описом.

Щоб скласти формальний опис, необхідно, використовуючи функціональну схему БЗПД, увести безліч ii параметрів, що характеризують, і базис операторів, які встановлюють відношення між цими параметрами. Тому першим кроком при побудові формального опису БЗПД є визначення множини їх параметрів:

$$
\mathbf{Q}=\left\{q_{i}\right\}, i=\overline{1, n}
$$

і базису операторів:

$$
\mathbf{A}=\left\{A_{i}\right\}, i=\overline{1, m}
$$

Під параметрами БЗПД далі розуміються постійні або змінні в часі величини, які характеризують стан БЗПД в даний момент часу, задають їх властивості й характеристики. При цьому структура БЗПД визначається функціональною схемою, елементи якої повинні бути описані відповідними операторами A, з множини $\mathbf{A}(8)$.

Всі параметри (7) БЗПД можна розбити на чотири підмножини:

$$
\mathbf{Q}=\{V, \alpha, \beta, \gamma\}
$$

де $V=\left\{v_{i}\right\}(i=\overline{1, k})$ - фазові змінні (координати) системи; $\alpha=\left\{\alpha_{i}\right\}(i=\overline{1, l})$ зовнішні параметри; $\beta=\left\{\beta_{i}\right\}(i=\overline{1, m})$ - внутрішні параметри; $\gamma=\left\{\gamma_{i}\right\}(i=\overline{1, n})$ - вихідні параметри.

Фазовими змінними БЗПД називаються функції часу $v_{i}$, які визначають стан БЗПД в будь-який заданий момент часу $t$. До складу множини фазових змінних $V$ входять:

$\mathbf{X}=\left\{x_{i}\right\} \quad(i=\overline{1, q})-$ зовнішні або вхідні фазові змінні, утворюючі вектор вхідних впливів;

$\mathbf{Y}=\left\{y_{i}\right\}(i=\overline{1, p})-$ вихідні фазові змінні, утворюючі вектор реакції БЗПД;

$\mathbf{Z}=\left\{z_{i}\right\}(i=\overline{1, f})-$ внутрішні фазові змінні.

Onepamop $A_{i}(i=\overline{1, m})$ являє собою правило, за яким кожному елементу $x_{i}$ множини $\mathbf{X}$ вхідних фазових змінних (випадкових або детермінованих) 
ставиться в однозначну або взаємооднозначну відповідність елемент $y_{i}$ множини Y вихідних фазових змінних. При цьому має місце наступне операторне рівняння:

$$
\mathbf{Y}=\mathbf{A} \mathbf{X}
$$

Число різних функціональних ланок, з яких можна скласти функціональну схему БЗПД на будь-якому ієрархічному рівні, кінцеве. Тому для формального опису БЗПД на заданому ієрархічному рівні досить увести кінцеву множину (алфавіт) операторів:

$$
\mathbf{A}=\left\{A_{i}\right\}, i=\overline{1, M}
$$

Ця множина називається базисом операторів.

Зовнішніми параметрами БЗПД $\alpha$ називають фізичні величини, чисельні значення яких визначають характеристики вхідних фазових змінних $\mathbf{X}$. Вектор вхідних дій, таким чином, можна описати наступним співвідношенням:

$$
\mathbf{X}=\mathbf{X}(\alpha, t)
$$

Внутрішніми параметрами БЗПД $\beta$ називають фізичні величини, чисельні значення яких характеризують властивості функціональних ланок, що утворять БЗПД й описуються операторами множини А. При цьому оператори можна представити наступним співвідношенням:

$$
\mathbf{A}=\mathbf{A}(\beta)
$$

Сформульовані визначення дозволяють увести поняття формального опису БЗПД і відповідної математичної моделі. У загальному випадку формальний опис БЗПД визначається операторним рівнянням (9). Із врахуванням уведених зовнішніх (11) і внутрішніх (12) параметрів це рівняння приймає вигляд:

$$
\mathbf{Y}(t)=\mathbf{A}(\beta) \mathbf{X}(\alpha, t),
$$

де $\alpha$ й $\beta$ у свою чергу можуть бути функціями часу $t$. Формальна схема БЗПД, що відображає цей опис, показана на рис. 2.

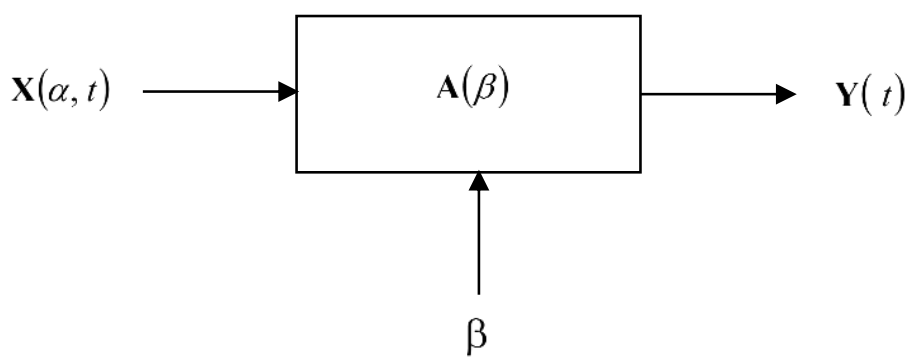

Рис. 2 - Формальна схема БЗПД 
Рівняння (13) описує множину різних БЗПД. Щоб описати конкретний БЗПД, необхідно уточнити й деталізувати оператор $\mathbf{A}(\beta)$. Якщо далі ввести обмеження й допущення щодо функціонування, то з формального опису може бути отримана математична модель конкретного БЗПД. Залежно від характеру обмежень і допущень математичні моделі будуть різними. Таким чином, 3 формального опису (13) можна одержати множину моделей БЗПД.

Вхідним параметром БЗПД є фізична величина, чисельне значення якої характеризує якість роботи БЗПД. Множина вихідних параметрів БЗПД $\gamma=\left\{\gamma_{i}\right\}(i=\overline{1, n})$ дозволяе кількісно оцінити правильність роботи і якість виконання поставленого завдання. Для оцінки множини вихідних параметрів $\gamma$ формальний опис БЗПД в загальному виді можна представити співвідношенням:

$$
\gamma=F_{1}(\mathbf{A}, \beta, \alpha)
$$

де $\mathbf{A}$ - оператор, що відображає структуру БЗПД. Такий опис у замкнутій формі можна одержати лише в результаті серйозного теоретичного аналізу, і то лише в найпростіших випадках.

При моделюванні адаптивної зміни параметрів БЗПД на ЕОМ застосовується наступний формальний опис вихідних параметрів:

$$
\gamma=F_{2}[\mathbf{Y}(t)]
$$

де $\mathbf{Y}(t)=\left\{y_{i}(t)\right\} \quad\left(i=\overline{1, p} ; 0 \leq t \leq T_{n} ; T_{\text {н }}-\right.$ час спостереження реалізації). Тут вихідний параметр отримується у результаті обробки вибірки обсягом $p$ з ансамблю реалізацій вихідної фазової змінної $\mathbf{Y}$.

Формальна схема моделювання адаптивної зміни параметрів БЗПД на ЕОМ, у результаті якого можна одержати оцінку $\widehat{\gamma}$ вихідного параметра, показана на рис. 3 .

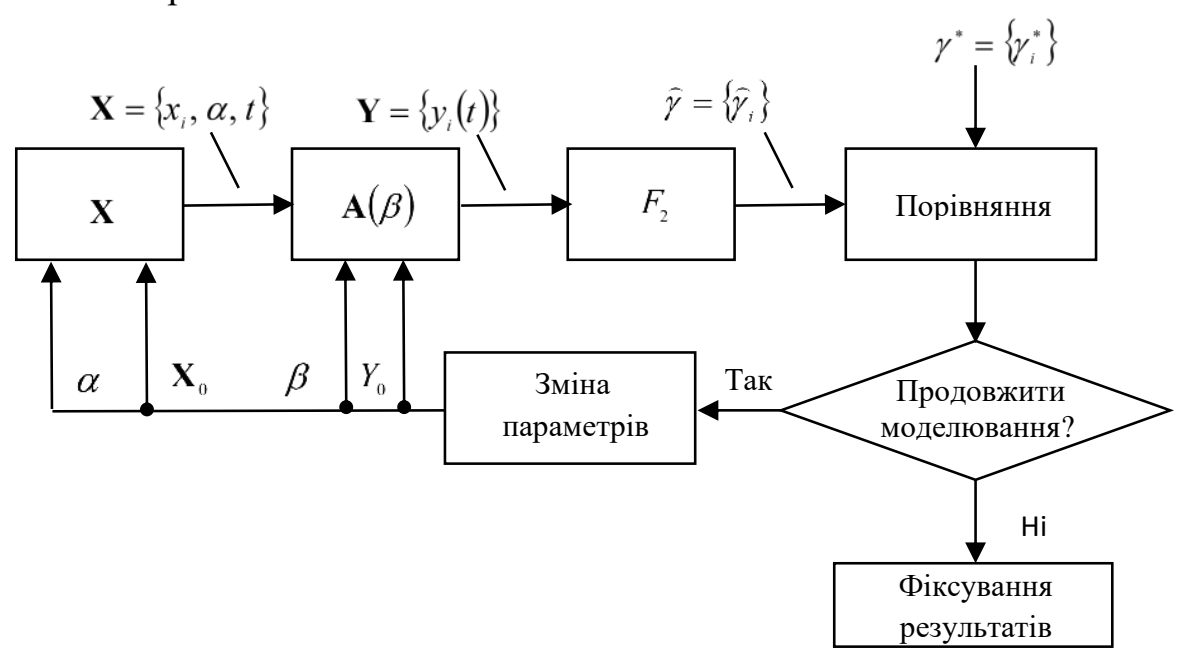

Рис. 3 - Формальна схема моделювання адаптивної зміни параметрів БЗПД на ЕOM 
Тут завдання вирішується методом статистичного моделювання, тобто шляхом багаторазових прогонів моделі при заданих початкових умовах $\mathbf{Y}_{0} \mathrm{i}$ $\mathbf{X}_{0}$, параметрах системи $\alpha$ й $\beta$.

$\mathrm{У}$ блоці $\mathbf{X}$ формується $p$ незалежних реалізацій вхідних фазових змінних $\mathbf{X}=\left\{x_{i}, \alpha, t\right\}(i=\overline{1, p})$. Ці реалізації надходять у блок $\mathbf{A}$, який $є$ реалізованою на ЕОМ математичною моделлю системи забезпечення достовірності інформації в БЗПД на основі адаптації кодових конструкцій, яка відображає ті або інші іiі особливості. На виході блоку А одержуємо $p$ реалізацій вихідних фазових змінних $\mathbf{Y}(t)=\left\{y_{i}(t)\right\}\left(i=\overline{1, p} ; 0 \leq t \leq T_{\text {н }}\right)$. Для стохастичних систем у загальному випадку $\mathbf{Y} \epsilon$ нестаціонарним випадковим процесом з багатомірним розподілом. $\mathrm{y}$ блоці $F_{2}$ здійснюється перетворення й статистична обробка вибірки $\mathbf{Y}$, у результаті якої одержуємо оцінку вихідного параметра $\hat{\gamma}$.

Далі отримані оцінки $\hat{\gamma}$ порівнюються 3 необхідними значеннями $\gamma^{*}$ вихідних параметрів, обумовленими технічним завданням на проектування БЗПД. На підставі порівняння виноситься рішення про подальшу процедуру моделювання. Якщо результат порівняння $\hat{\gamma}$ й $\gamma^{*}$ незадовільний, то приймається рішення про припинення досліджень і результати моделювання фіксуються у вигляді документа.

Таким чином, для моделювання БЗПД необхідно мати у своєму розпорядженні формальний опис щодо множини вихідних параметрів $\gamma=\left\{\gamma_{i}\right\}$ $(i=\overline{1, n})$. Вихідні параметри, які використовуються для оцінки якості функціонування системи, тісно пов'язані 3 конкретними завданнями, що підлягають рішенню методами моделювання на ЕОМ. Такими вихідними параметрами можуть бути техніко-економічна ефективність, технічна ефективність, показники якості.

У процесі дослідження БЗПД і пристроїв вирішується широке коло задач. Типовими задачами, які можуть вирішуватися методами математичного моделювання на ЕОМ, $\epsilon$ :

- задачі дослідження операцій, у яких застосовуються різні БЗПД;

- дослідження й проектування БЗПД і комплексів;

- задачі оптимізації управління БЗПД, комплексами й технологічними процесами.

Постановку цих задач i можливі шляхи їхнього рішення можна сформулювати, якщо скористатися розглянутим вище формальним описом БЗПД.

Для рішення задач дослідження операцій широко використовують статистичні моделі, які відображають послідовність розвитку подій при функціонуванні системи. Статистичні моделі дослідження операцій - перший крок моделювання БЗПД при їх проектуванні. Формальним описом БЗПД в дослідженні операцій приймемо сукупність операторних рівнянь, які встановлюють залежність ефективності системи Э по заданому показнику від iii основних параметрів:

$$
\ni=F_{1}(\mathbf{Q}), \mathbf{Q}=\{V, \alpha, \beta, \gamma\} .
$$


Таким чином, сутність статистичного моделювання при рішенні задач дослідження операцій зводиться до синтезу деякого моделюючого алгоритму, який імітує поводження й взаємодію елементів БЗПД 3 врахуванням випадкових факторів, що дозволяє оцінювати ефективність БЗПД (16).

Формальним описом БЗПД при дослідженні $є$ сукупність операторних рівнянь, яка встановлює залежність реакції системи $\mathbf{Y}(t)$ або іiі вихідного параметра $\gamma$ від основних внутрішніх і зовнішніх параметрів:

$$
\begin{gathered}
\mathbf{Y}(t)=\mathbf{A}(\beta) \mathbf{X}(\alpha, t), 0 \leq t \leq T_{\text {н }}, \\
\gamma=F_{1}(\mathbf{A}, \alpha, \beta) \text { або } \\
\gamma=F_{2}[\mathbf{Y}(t)], \mathbf{Y}(t)=\mathbf{Y}[\beta, \mathbf{X}(\alpha, t), t], 0 \leq t \leq T_{\text {н }},
\end{gathered}
$$

де $t$ - незалежна змінна (час). Під вихідними параметрами $\gamma$ в цьому випадку розуміють показники якості або технічну ефективність досліджуваного БЗПД.

Особливістю моделювання при рішенні цього роду задач $є$ наявність вичерпної інформації про БЗПД для переходу від формального опису (17), (18) до математичних моделей.

Формальним описом БЗПД при проектуванні є сукупність операторних рівнянь, які встановлюють залежність ефективності БЗПД від структури, основних параметрів і зовнішніх впливів:

$$
\ni=F_{1}[\mathbf{A}(\beta), \mathbf{X}(\alpha, t)] .
$$

У процесі проектування БЗПД задачу прагнуть вирішити щонайкраще, тобто забезпечити умову Э= extr .

Формальним описом БЗПД, що використовується при управлінні комплексом або процесом, $\epsilon$ сукупність операторних рівнянь, що встановлюють залежність ефективності комплексу від основних параметрів і реакцій при заданих зовнішніх впливах:

$$
\text { Э }=F(\mathbf{Q}, \mathbf{Y}) \text { при } \mathbf{X}=\mathbf{X}(\alpha, t) \text {. }
$$

Використання таких математичних моделей у складі комплексу дозволяє оптимізувати якість управління в складних ситуаціях роботи.

У процесі дослідження й проектування БЗПД виникає необхідність у вирішенні наступних інженерних задач:

- аналіз характеристик фазових змінних X і Y;

- аналіз характеристик БЗПД, які описуються операторами $\mathbf{A}$, або утворюючих їх функціональних ланок;

- оцінка показників якості К БЗПД, які характеризують точність, завадостійкість, надійність і т.п.;

- оцінка ефективності БЗПД в цілому;

- оцінка критичних значень зовнішніх $\alpha$ або внутрішніх $\beta$ параметрів БЗПД;

- оптимізація параметрів $\alpha$ і $\beta$ за заданим критерієм;

- вибір найкращої структури БЗПД $A^{*}$ з множини А можливих варіантів (функціональне проектування). 
Багато завдань із зазначених можна вирішити, одержавши оцінку технічної ефективності досліджуваних або проектованих БЗПД. Однак для цього необхідно мати у своєму розпорядженні відповідні критерії оцінки. Розглянемо можливі способи вибору критерію.

БЗПД відносяться до складних стохастичних систем, тому їх ефективність варто оцінювати ймовірнісними критеріями. Такими критеріями можуть бути:

- ймовірність настання події $B$, полягає в тому, що БЗПД виконає поставлену задачу повністю:

$$
\ni_{1}=P(B), 0 \leq \ni_{1} \leq 1
$$

- математичне очікування деякої випадкової величини $B$ :

$$
\ni_{2}=\mathbf{M}[B]=\mathbf{M}\left[\mathbf{Y}\left(t_{1}\right)\right], 0 \leq t_{1} \leq T_{\mathrm{H}} ;
$$

- дисперсія випадкової величини $B$ :

$$
\ni_{3}=\mathbf{D}[B]=\mathbf{D}\left[\mathbf{Y}\left(t_{1}\right)\right], 0 \leq t_{1} \leq T_{\mathrm{H}} .
$$

Розглянемо деякі особливості уведених критеріїв.

Критерій (21) визначає якість роботи БЗПД відповідно до принципу «все або нічого», «так чи ні», наприклад, передані або не передані повідомлення. У загальному випадку технічна ефективність БЗПД у вигляді (21) визначається наступним співвідношенням:

$$
\Im_{1}=P(B)=\int_{G} W\left(q_{1}, q_{2}, \ldots, q_{n}\right) d q_{1} d q_{2} \ldots d q_{n}, q_{i} \in G
$$

де $W\left(q_{1}, q_{2}, \ldots, q_{n}\right)$ - багатомірна функція розподілу щільності ймовірності рішення БЗПД поставленої задачі; $\mathbf{Q}=\left\{q_{i}\right\}(i=\overline{1, n})$ - множина параметрів, які безпосередньо впливають на ймовірність виконання БЗПД поставленої задачі; $G$ - область значень, які приймають параметри БЗПД в процесі їх функціонування.

Для оцінки технічної ефективності цим способом необхідно спочатку знайти багатомірний розподіл $W(\mathbf{Q})$. Методом моделювання на ЕОМ можна знайти лише гістограму розподілу, тобто оцінку $\widehat{W}(\mathbf{Q})$, i за умови, що множина $\mathbf{Q}$ містить один-два параметри.

Другий спосіб визначення ефективності - безпосереднє використання статистичного моделювання БЗПД. При цьому ефективність можна оцінити як:

$$
\ni_{1}=\widehat{P}(B)=n_{B} / N
$$

де $N$ - обсяг вибірки з ансамблю реалізацій (числа випробувань моделі БЗПД); $n_{B}-$ число випробувань, які завершилися виконанням БЗПД поставленої задачі. 
Ефективність повинна бути визначена з урахуванням множини показників якості $\mathbf{K}=\left\{K_{i}\right\}(i=\overline{1, m})$. Як вже відзначалося, всі показники взаємозалежні й оцінка технічної ефективності повинна проводитися 3 урахуванням цих зв'язків. Для цього необхідно мати досить детальну й складну математичну модель БЗПД, що складно, особливо на початкових стадіях проектування. Тому на початкових стадіях проектування ефективність БЗПД оцінюють по якому-небудь одному (частіше головному) показнику якості, наприклад надійності, пропускній спроможності, завадостійкості:

$$
\ni_{1}=P^{\mathrm{n}}(B) ; Э_{2}=P^{\mathrm{n}}(B) ; Э_{1}=P^{\mathrm{ny}}(B) .
$$

Для рішення кожної задачі повинні бути побудовані окремо відповідні математичні моделі.

Отже, підготовча робота, яку необхідно виконати до початку дослідження БЗПД на ЕОМ, у кожному конкретному випадку включає:

- розробку алгоритмів формування реалізацій вектора вхідної фазової змінної X;

- формування й реалізацію на ЕОМ математичної моделі, що підлягає дослідженню БЗПД для одержання реалізацій вихідної фазової змінної $\mathbf{Y}$;

- розробку програми для одержання чисельних значень вихідних параметрів БЗПД, які моделюються, що дозволяють оцінити якість їх функціонування.

Ця стаття містить неформальну частину, що вимагає для виконання високої кваліфікації, i формальну, котра в принципі може бути автоматизована. Автоматизація моделювання на своїй початковій стадії може полягати в тому, що формальна частина підготовчої роботи виконується заздалегідь і використовується далі дослідником по мірі необхідності.

\section{Висновки і пропозиції}

Запропоновано формалізацію структурної адаптації корегувальних кодів за умов впливу завад, які призводять до виникнення невизначеності в процесі декодування.

Сутність формалізації полягає у адаптивному виборі структури кодів 3 використанням апріорної та апостеріорної інформації декодера за рахунок мінімізації середнього ризику.

Запропоновані результати можна використати для математичного моделювання системи забезпечення достовірності інформації в БЗПД на основі адаптації кодових конструкцій.

\section{СПИСОК ЛІТЕРАТУРИ}

1. Помехозащищенность систем радиосвязи с расширением спектра сигналов методом псевдослучайной перестройки рабочей частоты / [Борисов В. И., Зинчук В. М., Лимарев А. Е. и др.]. - М.: Радио и связь, 2000. - 384 с.

2. Berrou C. Near Shannon Limit Error-Correcting Coding and Decoding: Turbo-Codes / C. Berrou, A. Glavieux, P. Thitimajshima // Proc. Int. Conf. On Commun., May 1993. 1993. - P. 1064-1070.

3. Holma H. HSDPA/HSUPA for UMTS: High Speed Radio Access for Mobile Communications / H. Holma, A. Toskala. - John Wiley \& Sons, 2006. - 268 p. 
4. Valenti M. The UMTS turbo code and an efficient decoder implementation suitable for software-defined radios / M. Valenti, J. Sun // Int. Journal of Wireless Inf. Networks. - 2001. Vol. 8, №4. - P. 203-215.

5. Consultative Committee for Space Data Systems "Recommendations for space data systems, telemetry channel coding" // BLUE BOOK. - 1998. - May.

6. 3GPP TS 25.212. Multiplexing and Channel Coding (FDD). 3GPP Technical Specification Group Radio Access Network, March 2005.

7. Digital Video Broadcasting (DVB): Interaction channel for satellite distribution systems (DVB-RCS) // ETSI EN 301790 V1.2. 1 (2000-07). - 2000. - February.

8. Ergen M. Mobile Broadband. Including WiMax and LTE / M. Ergen. - Springer, 2009. $513 \mathrm{p}$.

9. Zhenhuan W. Layered Adaptive Modulation and Coding For 4G Wireless Networks / W. Zhenhuan // Thesis presented to the University of Waterloo in fulfillment of the thesis requirement for the degree of Master of Applied Science in Electrical and Computer Engineering. - Waterloo, Ontario, Canada, 2011. - 49 p.

10. Jihoon K. A Simple SNR Representation Method for AMC Schemes of MIMO Systems with ML Detector / K. Jihoon, L. Kyoung-Jae, S. Chang Kyung, L. Inkyu // IEEE Transactions on Communications, Vol. 57, No. 10, October 2009. P. 2971-2976.

11. Liang Huang J. Adaptive MIMO Systems with Channel State Information at Transmitter / J. Liang Huang // PhD Thesis, KTH School of Information and Communication Technology, Stockholm, 2009. 79 p.

12. Goldsmith A. Variable-rate variable-power MQAM for fading channels / A. Goldsmith, S. Chua // IEEE Transactions on Communications, vol. 45, no.10, Oct. 1997. - P. 1218-1230. 13. Alouini S. Adaptive Modulation over Nakagami Fading Channels / S. Alouini, A. Goldsmith // Wireless Communications, vol. 13, no. 1-2, May 2000. - P. 119-143.

14. Maaref A. Rate-adaptive M-QAM in MIMO diversity systems using space-time block codes / A. Maaref, S. Aissa // in Proc. IEEE PIMRC 2004, vol. 4, Sep. 2004. - P. 2294-2298. 15. Репин В.Г. Статистический синтез при априорной неопределенности и адаптация информационных систем / В.Г. Репин, Г.П. Тартаковский. - М.: Советское радио, 1977. $432 \mathrm{c}$.

16. Woodard J. Comparative Study of Turbo Decoding Techniques: An Overview / J. Woodard, L. Hanzo // IEEE Transactions on Vehicular Technology. - 2000. - Vol. 49, N 6. - P. 2208-2232.

Стаття надійшла до редакиії 02.08.2019 і прийнята до друку після рещензування 29.08.2019

\section{REFERENCES (TRANSLATED AND TRANSLITERATED)}

1. Borisov, V. I., Zinchuk, V. M., Limarev, A. E., etc. (2000). Interference protection of radiocommunication systems with the expansion of the spectrum of signals by the method of pseudorandom tuning of the operating frequency. Moscow: Radio and communication. (in Russian).

2. Berrou, C., Glavieux, A., \& Thitimajshima, P. (1993). Near Shannon Limit ErrorCorrecting Coding and Decoding: Turbo-Codes. In Proc. Int. Conf. On Commun., May 1993 (pp. 1064-1070).

3. Holma, H., \& Toskala, A. (2006). Hsdpa/Hsupa for UMTS: High Speed Radio Access for Mobile Communications. John Wiley \& Sons.

4. Valenti, M., \& Sun, J. (2001). The UMTS turbo code and an efficient decoder implementation suitable for software-defined radios. Int. Journal of Wireless Inf. Networks, 8(4), 203-215.

5. Consultative Committee for Space Data Systems. (1998). "Recommendations for space data systems, telemetry channel coding. ” BLUE BOOK. 
6. 3GPP TS 25.212. Multiplexing and Channel Coding (FDD). (2005). 3GPP Technical Specification Group Radio Access Network.

7. Digital Video Broadcasting (DVB): Interaction channel for satellite distribution systems (DVB-RCS). (2000). ETSI EN 301790 V1.2. 1 (2000-07).

8. Ergen, M. (2009). Mobile Broadband. Including WiMax and LTE. Springer.

9. Zhenhuan, W. (2011). Layered Adaptive Modulation and Coding For 4G Wireless Networks. In Thesis presented to the University of Waterloo in fulfillment of the thesis requirement for the degree of Master of Applied Science in Electrical and Computer Engineering (49 p.). Ontario, Canada: University of Waterloo.

10. Jihoon, K., Kyoung-Jae, L., Chang Kyung, S., \& Inkyu, L. (2009). A Simple SNR Representation Method for AMC Schemes of MIMO Systems with ML Detector. IEEE Transactions on Communications, 57(10), 2971-2976.

11. Liang Huang, J. (2009). Adaptive MIMO Systems with Channel State Information at Transmitter (PhD Thesis). KTH School of Information and Communication Technology, Stockholm.

12. Goldsmith, A., \& Chua, S. (1997). Variable-rate variable-power MQAM for fading channels. IEEE Transactions on Communications, 45(10), 1218-1230.

13. Alouini, S., \& Goldsmith, A. (2000). Adaptive Modulation over Nakagami Fading Channels. Wireless Communications, 13(1-2), 119-143.

14. Maaref, A., \& Aissa, S. (2004). Rate-adaptive M-QAM in MIMO diversity systems using space-time block codes. In Proc. IEEE PIMRC 2004 (Vol. 4, pp. 2294-2298).

15. Repin, V. G., \& Tartakovsky, G. P. (1977). Statistical synthesis in a priori uncertainty and adaptation of information systems. Moscow: Soviet Radio. (in Russian).

16. Woodard, J., \& Hanzo, L. (2000). Comparative Study of Turbo Decoding Techniques: An Overview. IEEE Transactions on Vehicular Technology, 49(6), 2208-2232.

The article was received 02.08.2019 and was accepted after revision 29.08.2019

\section{Горлинський Борис Вікторович}

начальник управління Департаменту захисту інформації Адміністрації Державної служби спеціального зв'язку та захисту інформації України

Адреса робоча: 03110 Україна, м. Київ, вул. Солом’янська, 13

e-mail:vjzgoxnf@gmail.com

ORCID ID 0000-0002-9993-2427

\section{Зайцев Сергій Васильович}

професор кафедри інформаційних та комп'ютерних систем Чернігівського національного технологічного університету

Адреса робоча: 14000 Україна, м. Чернігів, вул. Шевченка, 95

e-mail: serza1979@gmail.com

ORCID ID 0000-0001-6643-917X

\section{Казнадій Світлана Петрівна}

старший викладач кафедри інформаційних та комп'ютерних систем Чернігівського національного технологічного університету

Адреса робоча: 14000 Україна, м. Чернігів, вул. Шевченка, 95

e-mail: kaznadeysp@gmail.com

ORCID ID 0000-0001-8516-0801

\section{Зайцева Лілія Ігорівна}

технік Державної служби спеціального зв'язку та захисту інформації України

Адреса робоча: 14000 Україна, м. Чернігів, вул. Шевченка, 28

e-mail: serza1979@gmail.com

ORCID ID 0000-0002-0668-711X 